\title{
Low Concentrating Photovoltaics (LCPV) for buildings and their performance analyses
}

\author{
Ranga Vihari Parupudi, Harjit Singh ", Maria Kolokotroni \\ Institute of Energy Futures, College of Engineering, Design and Physical Sciences, Brunel University London, Uxbridge UB8 3PH, UK
}

\section{H I G H L I G H T S}

- Three Low Concentrating Photovoltaic (LCPV) systems have been developed for building retrofit.

- Ray trace simulations are verified with the indoor experimentation.

- Daily, monthly and seasonal variation of predicted energy output is presented.

- The effect of cell temperature on energy generation is presented.

\section{A R T I C L E I N F O}

\section{Keywords:}

Low Concentrating Photovoltaics (LCPV)

Compound Parabolic Concentrator (CPC)

V-Trough

Asymmetric Compound Parabolic Concentrator (ACPC)

Photovoltaic-thermal (PV/T)

\begin{abstract}
A B S T R A C T
Low concentrating photovoltaic technologies (LCPV) for building application offer viable solutions in improving the conversion efficiency of solar cells leading to an improved electrical output per unit cell area required when compared to conventional solar photovoltaic modules. The current study explores the feasibility of different geometrically equivalent LCPVs designed for building application through indoor experimental characterisation and analytical investigations. LCPV concentrator geometries were designed and simulated to predict optical efficiency at various truncation levels and range of angles of incidence using ray trace module in COMSOL Multiphysics version 5.3. The geometric concentration ratios of LCPVs investigated Compound Parabolic Concentrator (CPC), V-Trough and Asymmetric Compound Parabolic Concentrator (ACPC) with geometric concentration ratios of $1.46,1.40$, and 1.53 respectively. These prototypes were manufactured and their electrical conversion efficiency in conjunction with crystalline silicon (c-Si) solar photovoltaic cells were measured using OAI Trisol Class AAA solar simulator. Analytical model developed in the present study predicts the annual energy output generated and payback period for the LCPVs compared to an equivalent area of conventional flat module. Theoretical modeling results have showed that Asymmetric Compound Parabolic Concentrator (ACPC) with mono-crystalline silicon cells (m-Si) have generated highest energy output per unit area of $177 \mathrm{kWh} / \mathrm{m}^{2}$ as compared to the other configurations which make it economically viable for building retrofit with a predicted payback period of 9.7 years.
\end{abstract}

\section{Introduction}

Buildings account for $40 \%$ of Europe's total energy consumption and $36 \%$ of $\mathrm{CO}_{2}$ emissions [1]. It has been reported that $75 \%$ of total existing European buildings are energy inefficient with $35 \%$ of them over 50 years old [2]. Hence, harnessing solar energy to generate power using wall/roof mounted photovoltaic (PV) systems offer an opportunity to enhance their energy efficiency. It also reduces their environmental impact for PV panels are noise free and emit no emissions during operation. No wonder, the cumulative solar PV installation capacity across Europe was $26.77 \mathrm{GW}$ in 2018 and estimated to pick up significantly from 2019 to 2024 to $50.39 \mathrm{GW}$ [3].

The amount of power generated and electrical conversion efficiency is dependent on the insolation (type and amount) available on PV cells. Optical concentrators can increase radiation intensity on the solar cell surface, which can reduce the amount of semiconductor material used in manufacturing PV panels, thus reduction in the overall PV module cost. High concentrating photovoltaic (HCPV) technologies account for $>90 \%$ of the global installed capacity though all CPV technologies with geometric concentration ratio $C_{\mathrm{g}}>10$ require solar tracker, which uses a proportion of the power generated, substantially increases the capital

\footnotetext{
* Corresponding author.

E-mail address: harjit.singh@brunel.ac.uk (H. Singh).
} 


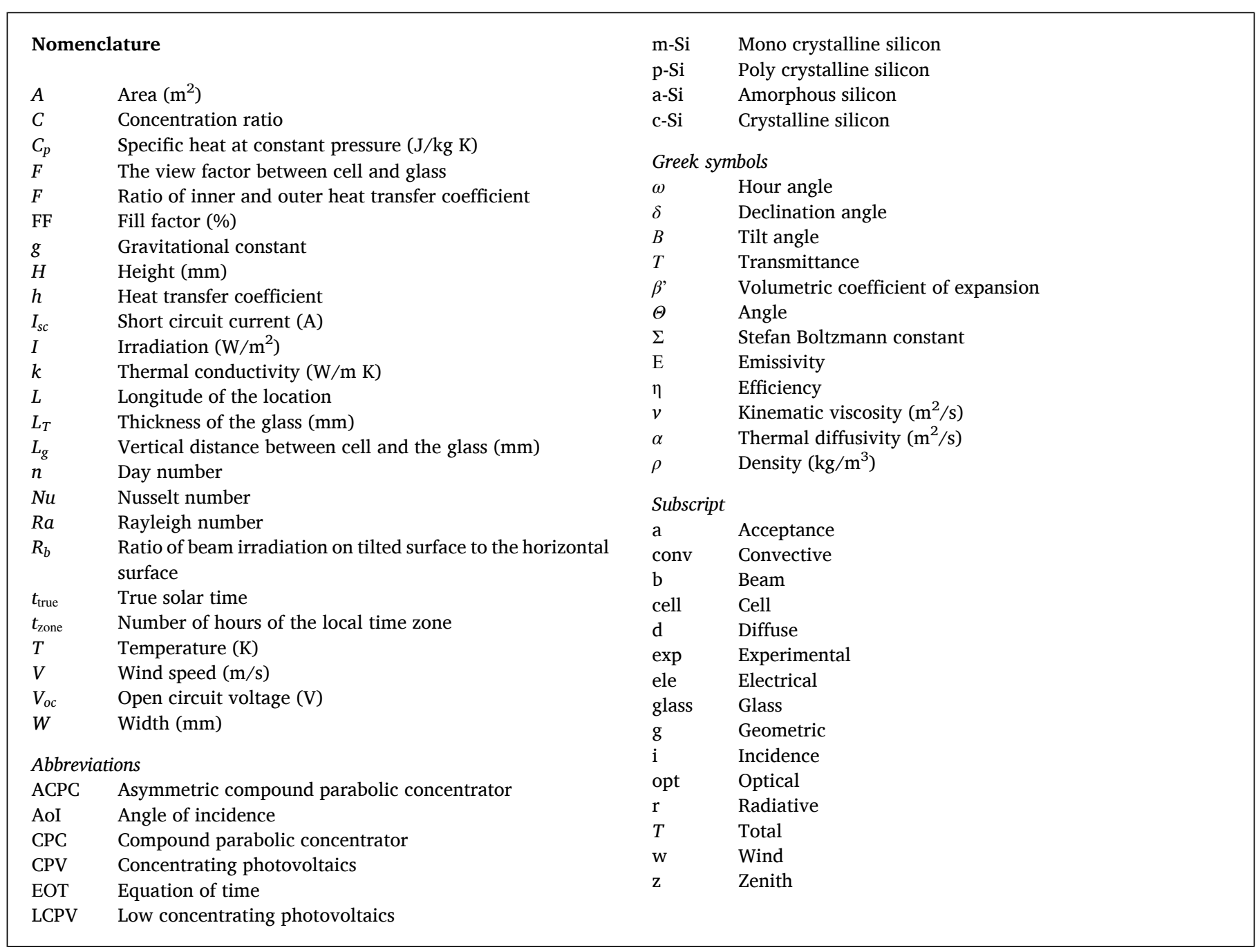

and maintenance costs and adds weight to the panel structure $[4,5]$. On the contrary, low concentrating photovoltaic (LCPV) technologies with $C_{\mathrm{g}} \leq 10$ are simpler in design, can harness a large part of solar spectrum whilst requiring no or a simple tracking mechanism requiring zero or minimum maintenance. The concentrators with $C_{\mathrm{g}} \leq 3$ with a capability to even harness a significant amount (factor of inverse of $C_{\mathrm{g}}$ ) of the diffuse solar radiation incident on the aperture are strong candidates for deployment in the geographic regions experiencing high diffused solar radiation component [6]. Clearly, these are best suited for building integration or retrofitting and have been investigated for several years by many research groups globally.

Compound parabolic concentrator (CPC) based CPV systems due to their ability to harness diffuse radiation gripped a lot of attention since they were first reported in 1974 [6]. Hasan et al. [7] have compared the electrical performance of actively cooled CPC PVT collectors using p-Si solar cells with a non-concentrating $\mathrm{p}$-Si solar panel. Results have showed that CPC with p-Si solar cells produced $62.5 \%$ higher than a nonconcentrating p-Si solar panel. Baig et al. [8] have reported a threedimensional crossed compound parabolic concentrator $(3.6 \mathrm{x})$ with flat $\mathrm{m}$-Si PV cells, which achieved a power ratio of 2.67 when compared to a flat PV panel. A novel mirror symmetrical dielectric totally internally reflecting concentrator was reported to achieve a concentration ratio of $13.45 x$, for radiation incident within its half acceptance angle, when compared to a non-concentrating solar cell [9]. Shaltout et al. [10] studied a dual axis tracked V-Trough concentrator in conjunction with p$\mathrm{Si}$ and a-Si solar cells. Sangani and Solanki [11] experimentally measured a $44 \%$ higher electrical energy produced by a seasonally tracked 2-sun V-Trough concentrator than a non-concentrating counterpart. Baig et al. [12] and Elminshawy et al. [13] have reported watercooled V-Trough concentrators with c-Si PV technology. Recently, Hadavinia and Singh [14] through an experimental study reported that a CPC with geometric concentration ratio of 2.7 generating $2.4 \%$ higher power than a geometrically equivalent V-Trough. These studies have shown CPC and V-Trough based LCPV systems in conjunction with c-Si solar PV technologies have several advantages as compared to the conventional flat panel devices in terms of a higher electrical conversion efficiency and an effective use of the roof space. However, their high performance is limited to within narrow acceptance angles these have been originally designed for, sacrificing optical concentration at angles of incidence outside this range.

Zachropolous et al. [15] have reported a comparative threedimensional optical analysis of both symmetric and asymmetric dielectric non-imaging concentrators for building applications. Later, Mallick et al. [16,17] and Mallick and Eames [18] experimentally found asymmetric compound parabolic concentrator (ACPC) with a flat m-Si PV module producing $62 \%$ more power than a flat PV module. Lu et al. [19] reported PCM cooled m-Si solar cells in conjunction with a truncated ACPC $(2 \mathrm{x})$ producing $10 \%$ higher electrical energy than a concentrator with no heat sink at rear end.

This paper presents a validated comparative assessment of energy output and payback period for three geometrically equivalent LCPV optical concentrator in conjunction with low cost c-Si cells. This 


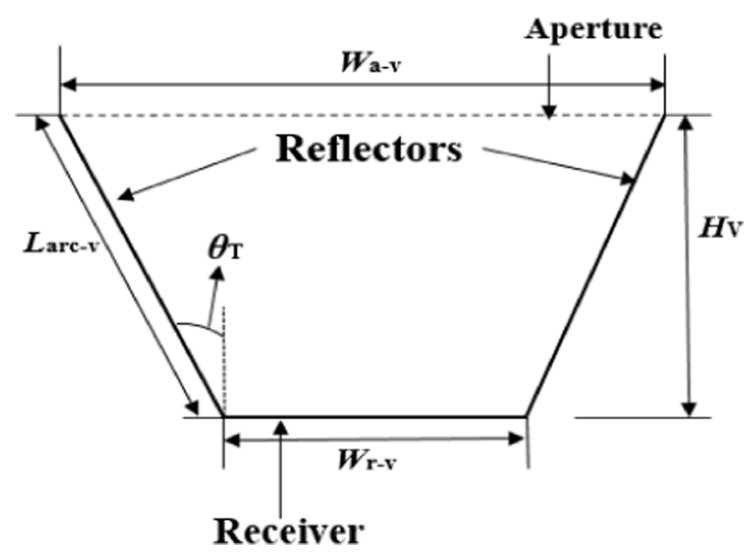

Fig. 1. Cross sectional view of V-Trough concentrator [20].

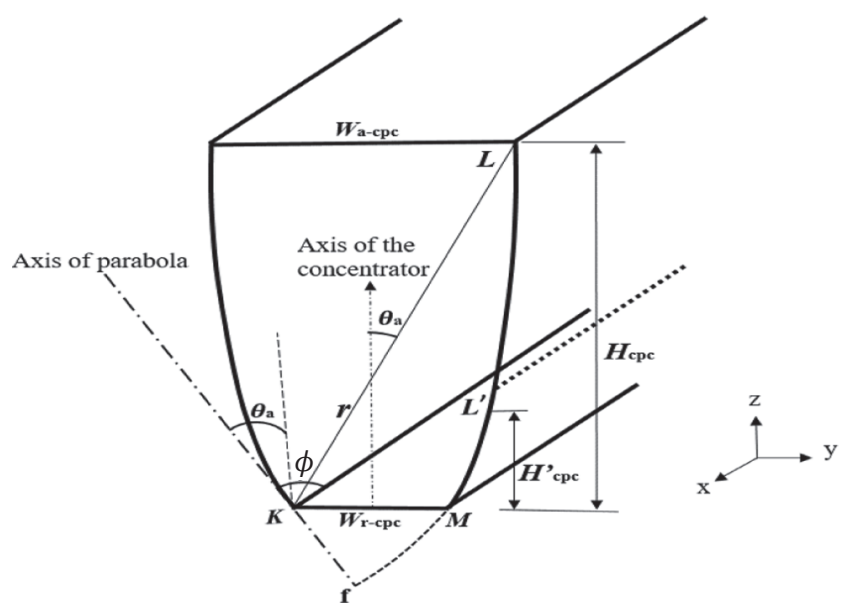

Fig. 2. Cross sectional view of a CPC concentrator [21].

demands a combined computer and lab test-based investigations into geometrically equivalent LCPV geometries in conjunction with low cost c-Si technologies focused on building integration or retrofit.

The measured difference among LCPV performances has been found to be a complex phenomenon as it involves several independent parameters that should be considered simultaneously. LCPV designs were developed and their optical performance at various angles of incidence predicted using ray-tracing tool in COMSOL Multiphysics. Led by the optical analysis three concentrator prototypes - ACPC (1.53x), CPC (1.46x) and V-Trough (1.40x) - were manufactured and tested in conjunction with commercially available c-Si solar cells under simulated solar conditions. The daily, monthly and annual energy output and payback period of the LCPV modules are presented with a view to identify the best CPV module for fitting onto buildings, new or existing, by employing an in-house analytical tool developed in the study.

\section{CPV geometries}

\subsection{V-trough concentrator}

A V-Trough concentrator consists of two flat reflectors inclined at an angle $\left(\theta_{\mathrm{T}}\right)$ to the axis normal to the receiver as shown in Fig. 1. Two flat mirrors focus solar irradiance incident on the aperture onto the receiver. Critical parameters governing the ray acceptance in a V-Trough design consist of trough angle $\left(\theta_{\mathrm{T}}\right)$, concentration ratio $\left(C_{\mathrm{g}}\right)$ and the height of concentrator $\left(H_{\mathrm{v}}\right)[20]$.

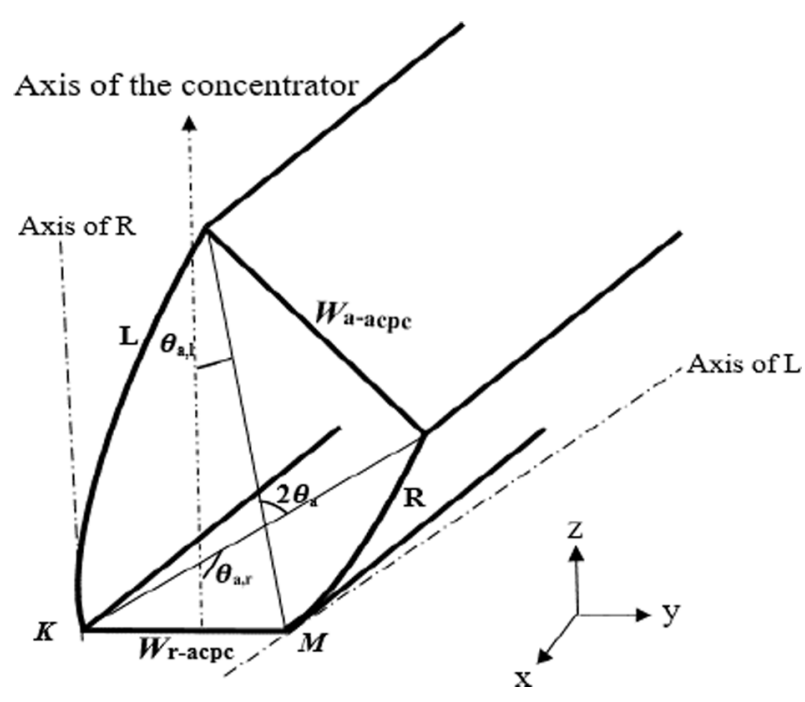

Fig. 3. Cross sectional view of ACPC concentrator [23].

\subsection{Compound parabolic concentrator (CPC)}

A symmetric compound parabolic concentrator (CPC) consists of two parabolic reflectors with equal half acceptance angle $\left(\theta_{\mathrm{a}}\right)$ located on the both sides of the receiver. This design achieves the highest optical efficiencies resulting into the maximum theoretical concentration on the receiver provided the solar radiation falls at aperture within acceptance angle $\left( \pm \theta_{\mathrm{a}}\right)$. The profile of the CPC between $(L)$ and $(M)$ consists of a parabola with the focus at $K$, as shown in Fig. 2. The equation of any parabola in polar coordinates is represented in Eq. (1).

$r=\frac{2 f}{1-\cos \phi}$

With the origin for Cartesian coordinates at the centre of receiver $K M$ and z-axis along the height of concentrator, the parametric representation of CPC can be determined from Eq. (2) and Eq. (3). The angular expanse of $(r)$ for a full height CPC $\left(H_{\text {cpc }}\right)$ varies from $2 \theta_{\mathrm{a}} \leq \phi(L M) \leq$ $\Pi / 2+\theta_{\mathrm{a}}[21]$. Truncating CPC facilitates some rays incident at aperture at $\theta_{\mathrm{i}}>\theta_{\mathrm{a}}$ reaching the receiver, without significant loss in the optical efficiency. Truncation of side walls reduces reflector material required, weight and the height of a CPC to ease its building application [22]. The arc length of the reflector wall is determined by the angular position of $r$ in relation to $\theta_{\mathrm{a}}$, which is then rotated at $\phi$ resulting in the truncated arc length $L^{\prime}$.

$y=\frac{2 a^{\prime}\left(1+\sin \theta_{\mathrm{a}}\right) \sin \left(\phi-\theta_{\mathrm{a}}\right)}{1-\cos \phi}-\frac{W_{r-c p c}}{2}$

$z=\frac{2 a^{\prime}\left(1+\sin \theta_{\mathrm{a}}\right) \cos \left(\phi-\theta_{\mathrm{a}}\right)}{1-\cos \phi}$

\subsection{Asymmetric Compound Parabolic Concentrator (ACPC)}

An asymmetric CPC is an exceptional case of symmetric CPC, introduced by Rabl [23]. Fig. 3 presents the cross-sectional view of an asymmetric CPC with acceptance angles $\left(2 \theta_{\mathrm{a}}=\theta_{\mathrm{a}, \mathrm{l}}+\theta_{\mathrm{a}, \mathrm{r}}\right)$. The axis of left parabola subtends an angle $\left(\theta_{\mathrm{a}, 1}\right)$ to the axis of the concentrator with its focus on the right parabola $(M)$. In addition, the axis of right parabola subtends an angle $\left(\theta_{\mathrm{a}, \mathrm{r}}\right)$ with the concentrator axis with focus on the left parabola $(K)$.

\section{Ray trace modelling}

Optical analysis of LCPV designs in this research involved CPC, V- 


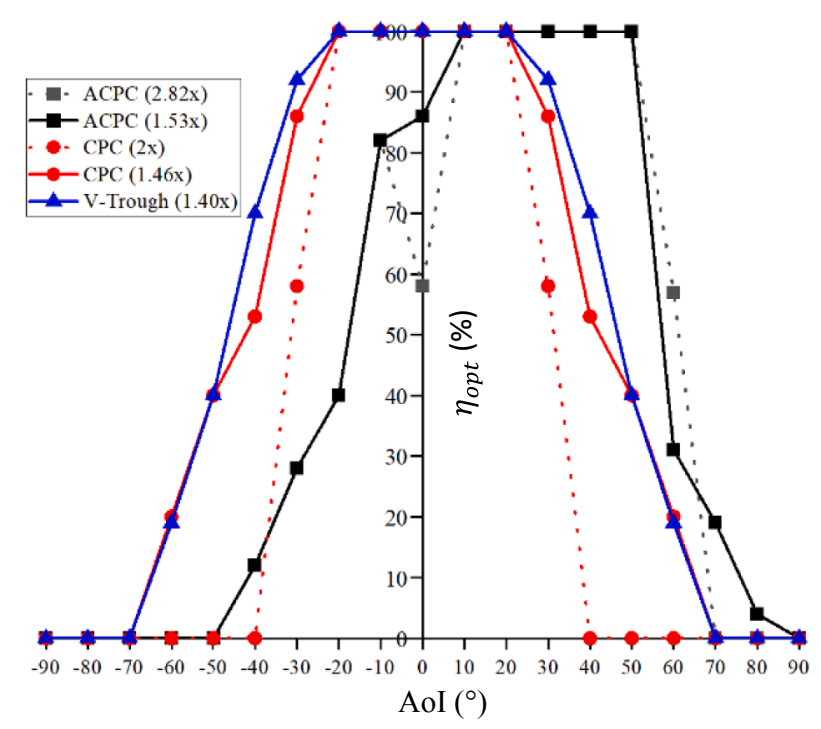

Fig. 4. Angular acceptance of the LCPV designs investigated at different AoI.

Trough and ACPC geometries using ray optics module in COMSOL Multiphysics. The optical analysis of the LCPV designs have been simulated by considering direct irradiation as a function of angle of incidence (AoI) on the aperture of the concentrator as the diffused radiation is not directional therefore independent of AoI. The design of the reflector walls has been simplified by using parametric curve in COMSOL which solved the critical variables such as $\phi$ and $\theta_{\mathrm{i}}$ from the Eqs. (2) and (3). The number of simulations required to investigate CPV designs at different truncation levels, varying AoI, could be very large. For instance, investigating a full height $\mathrm{CPC}$ varying AoI from $0^{\circ}$ to $90^{\circ}$ at three levels of truncation requires $91 \times 3=273$ simulations, for a specified half acceptance angle $\theta_{\mathrm{a}}$. This step has been condensed to 3 simulations using parametric sweep tool which allowed to test a range of angular intervals. The ray trace simulations in COMSOL require concentrator geometry with an inlet, reflectors and a receiver and optical properties of each concentrator component allowing a time dependent study.

The following boundary conditions were employed in this study.

(i) Ray properties were specified to a wavelength of $550 \mathrm{~nm}$.

(ii) Reflector walls were inputted with a reflection coefficient of 0.98 with a primary wall condition of specular reflection.

(iii) Wall condition for the receiver was set to freeze rays.

(iv) Number of rays per release were specified to 1000.

The ray acceptances of full height and truncated concentrators are illustrated in Fig. 4. Ray trace simulation showed that all the rays incident at AoI within half acceptance angles $\left(\theta_{\mathrm{i}}<\theta_{\mathrm{a}}\right)$ reached the receiver of CPC and V-Trough collectors regardless of their level of truncation and geometric concentration ratio. However, truncated collectors only partially accept rays beyond half acceptance angles $\left(\theta_{\mathrm{i}}>\theta_{\mathrm{a}}\right)$, see Fig. 4, $\mathrm{CPC}$ showed a clear variation with AoI ranging from $0^{\circ}$ to $90^{\circ}$. However, at full and truncated heights the ACPC showed the highest ray acceptance only over $+\theta_{a}$ due to asymmetricity of its half acceptance angles, see Fig. 4. Fig. 5 presents an example ray trace graphs of ACPC and CPC under AoI ranging from 0 to $60^{\circ}$ respectively.

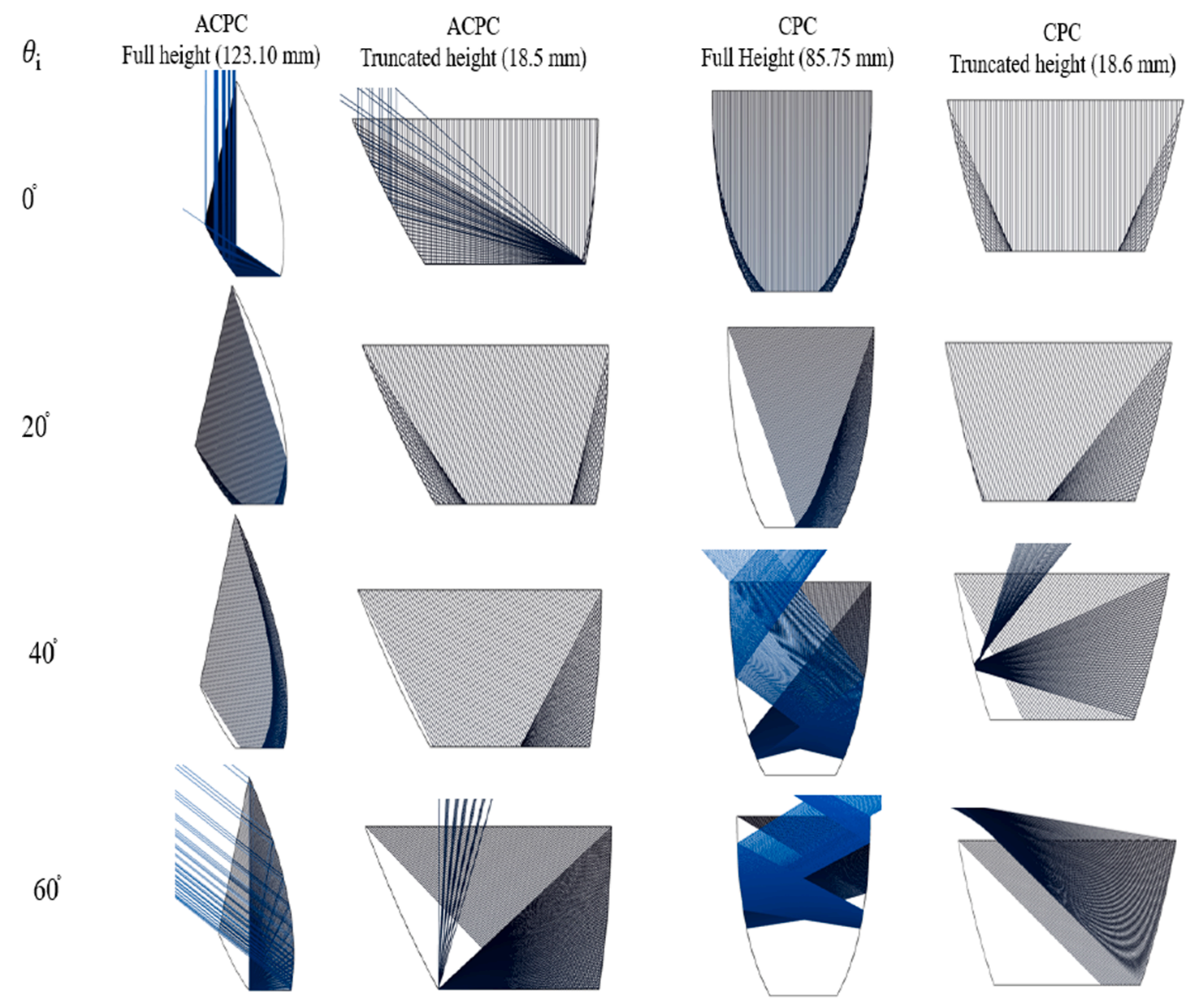

Fig. 5. Ray trace graphs of ACPC and CPC collectors at AoI ranging from $0^{\circ}$ to $60^{\circ}$. 


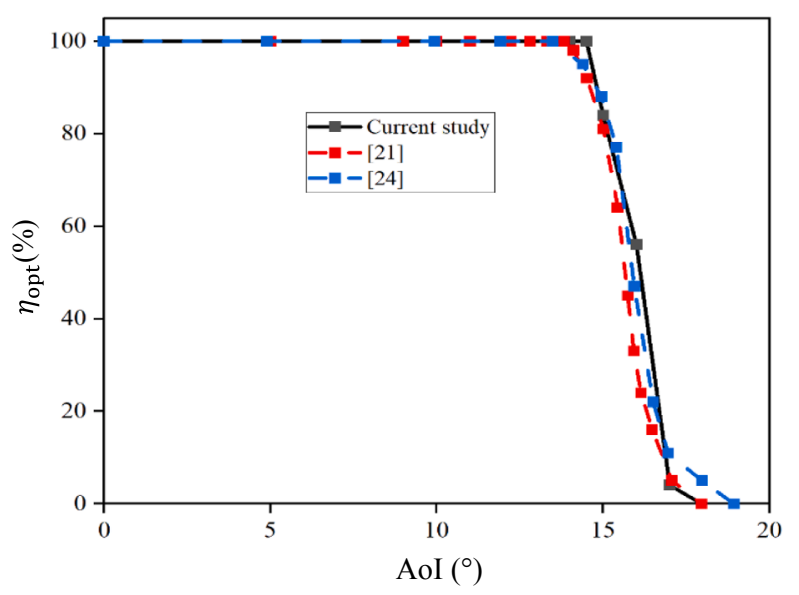

Fig. 6. Comparison of angular acceptance of a full height CPC of half acceptance angle of $16^{\circ}$.

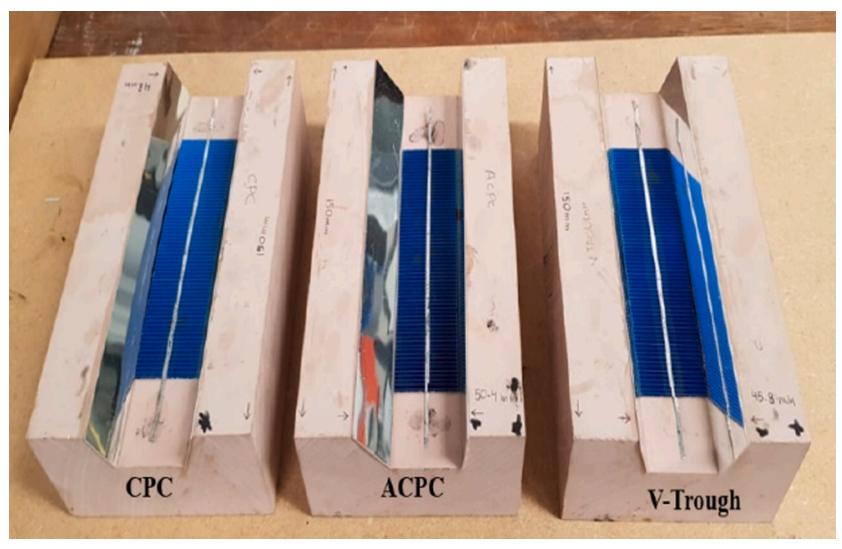

Fig. 7. LCPV prototypes developed and tested under solar simulator.

\subsection{CPC design validation}

A full height CPC concentrator was designed numerically with a half acceptance angle of $16^{\circ}$ and its ray acceptance was compared to the results from the studies reported by Winston et al. [21] and Li et al. [24]. The results showed that there is a deviation of $7.8 \%$ from the data reported, see Fig. 6.

\section{Concentrating collectors and testing}

\subsection{CPV systems description and construction}

For optical analysis, all three different LCPV geometries investigated were, truncated at different levels whilst keeping the same receiver width of $33 \mathrm{~mm}$. For ACPC, a full height concentrator with a geometric concentration ratio $\left(C_{\mathrm{g}}\right)$ of 2.82 and half acceptance angles $\left(\theta_{\mathrm{a}}\right)$ of $0^{\circ}$ and $60^{\circ}$ was considered. The full height ACPC was truncated to one-third height, which reduced the geometric concentration by $54.3 \%$. Similarly, a CPC with $\theta_{\mathrm{a}}=30^{\circ}$ and $C_{\mathrm{g}}=2$ truncated to $1 / 3^{\text {rd }}$ of its full height with a resulting final $C_{\mathrm{g}}$ of 1.46 was considered. A V-Trough concentrator with $C_{\mathrm{g}}$ of 1.40 and trough angle $\left(\theta_{\mathrm{T}}\right)$ of $20^{\circ}$ was also studied.

The geometries with preferred concentration ratios, receiver width and aperture width were designed in SolidWorks to facilitate the manufacturing phase using CNC milling machine. High-density polyurethane board was employed as substrate for prototyping these geometries. The reflectors in CPV systems demand high reflectivity with minimum optical losses and durability. MIRO-SILVER 4200 AG [25] with a total reflectivity of 0.98 in the visible range was employed.

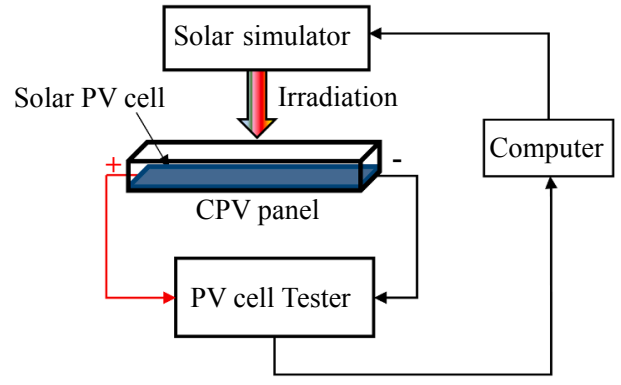

Fig. 8a. Schema of the experimental setup for the electrical conversion efficiency measurements.

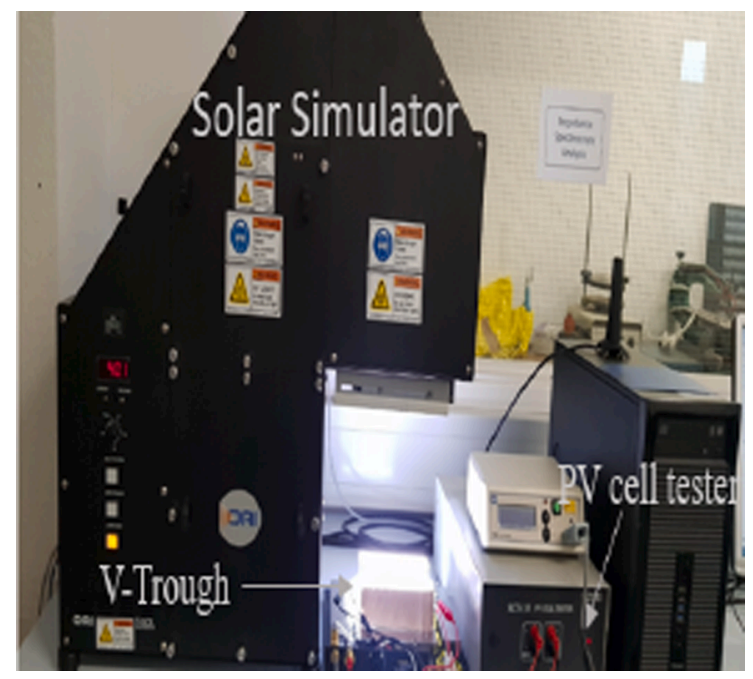

Fig. 8b. Testing V-Trough concentrator under OAI solar simulator at normal incidence.

Table 1

Measured properties of the solar cells studied.

\begin{tabular}{lll}
\hline Cell type & $\mathrm{m}-\mathrm{Si}$ & $\mathrm{p}-\mathrm{Si}$ \\
\hline Cell Dimensions $\left(\mathrm{mm}^{2}\right)$ & $98 \times 30$ & $98 \times 31$ \\
$V_{o c}(\mathrm{~V})$ & 0.65 & 0.60 \\
$I_{s c}(\mathrm{~A})$ & 1.13 & 1.05 \\
$\eta_{\max }(\%)$ & 17.62 & 15.54 \\
$F F(\%)$ & 73 & 73.94 \\
\hline
\end{tabular}

Concentrator walls were formed by gluing reflector sheets to the sides of the substrate, as shown in Fig. 7.

\subsection{Electrical conversion efficiency measurements}

The electrical conversion efficiency measurements of the m-Si, p-Si solar PV cells in conjunction with the manufactured CPV prototypes were performed using an OAI Trisol class AAA solar simulator. LCPV prototypes with solar PV cells were positioned on the tilting table, placed on the illuminated area of simulator, allowing testing done at a range of AoIs. Regulating the power supply to the solar simulator allowed current and voltage measurements of solar cells under variable beam intensities. An electronic SCT-110 PV cell Tester was used to measure the current and voltage output of the solar cells and the electrical conversion efficiency of cell at maximum power output were measured. The schematic of the experimental setup and testing VTrough concentrator are shown in Fig. 8a and Fig. 8b. The measured properties of the solar PV cells presented in Table 1. 


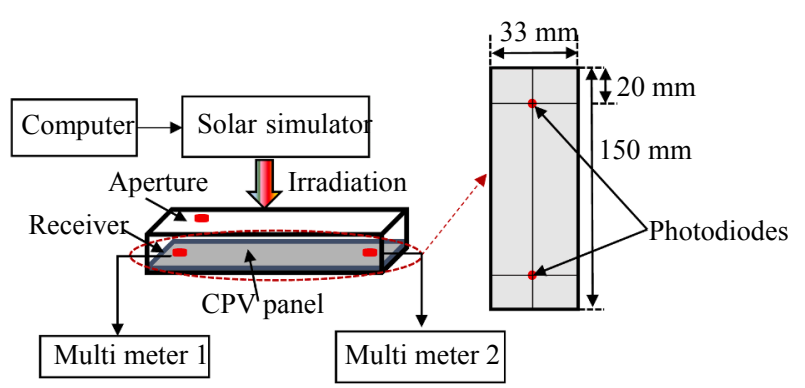

Fig. 9. Layout of the experimental setup for optical efficiency measurements.

Table 2

Variables used in the analytical model.

\begin{tabular}{lll}
\hline Variables & Value & Source \\
\hline Tilt angle, $\beta$ & $51.51^{\circ}$ & - \\
Latitude of the location, $\phi$ & $51.51^{\circ} \mathrm{N}$ & - \\
Longitude of the location, $L$ & $0.45^{\circ} \mathrm{W}$ & - \\
Ground reflectivity coefficient, $\rho_{g}$ & 0.22 & {$[28]$} \\
\hline
\end{tabular}

\subsection{Optical concentration measurements}

The optical efficiency of the developed prototypes CPC, V-Trough and ACPC was measured using OSRAM SFH 203P photo diodes, with a spectral range of 400-1000 $\mathrm{nm}$ and the radiant sensitive area of $1 \times 1$ $\mathrm{mm}^{2}[26]$. To measure the radiant flux, two photodiodes were placed on the receiver and one on the concentrator aperture, see Fig. 9, and the generated voltage recorded with digital multi meters.

The experimental optical efficiency ( $\eta_{\text {exp,opt }}$ ) is calculated as a ratio of the radiant flux received at the receiver $\left(I_{\text {receiver }}\right)$ to the product of the radiant flux incident on the concentrator aperture $\left(I_{\text {aperture }}\right)$ and the geometrical concentration ratio $\left(C_{\mathrm{g}}\right)$; see Eq. (4).

$\eta_{\text {exp }, \text { opt }}=\frac{I_{\text {receiver }}}{I_{\text {aperture }} \times C_{\mathrm{g}}}$

The optical concentration ratio $\left(C_{\mathrm{opt}}\right)$ of the concentrators has been calculated using Eq. (5).

$C_{\text {opt }}=\eta_{\text {exp }, \text { opt }} \times C_{\mathrm{g}}$

\section{Annual energy generated by the solar concentrators}

\subsection{Model for the electrical power generation}

A computer model has been developed to predict the technoeconomic viability of the LCPV panels and the flat PV modules. In the model, the solar irradiation data (global and diffused) and climate file for London has been employed from the design reference year [27]. Beam, isotropic diffuse and the diffused radiation reflected from neighbouring and received on the aperture of the PV panels have been considered [28].

The electrical output and thermal resistance of the various solar PV technologies were studied numerically by Palencia et al. [29], Orioli et al. [30], Lurwan et al. [31]. A novel approach has been developed in this study to predict the solar radiation incident on the receiver (PV cells) using the measured optical concentration of the LCPV systems through indoor experiments. The radiation intensity incident on the solar cells determine the electrical output, heat gained and lost by the PV cells. The variables inputted to the model are presented in Table 2. Total irradiation, $I_{\mathrm{T}}\left(\mathrm{W} / \mathrm{m}^{2}\right)$ on a tilted surface $(\beta)$ for an hour is determined using Eq. (6).

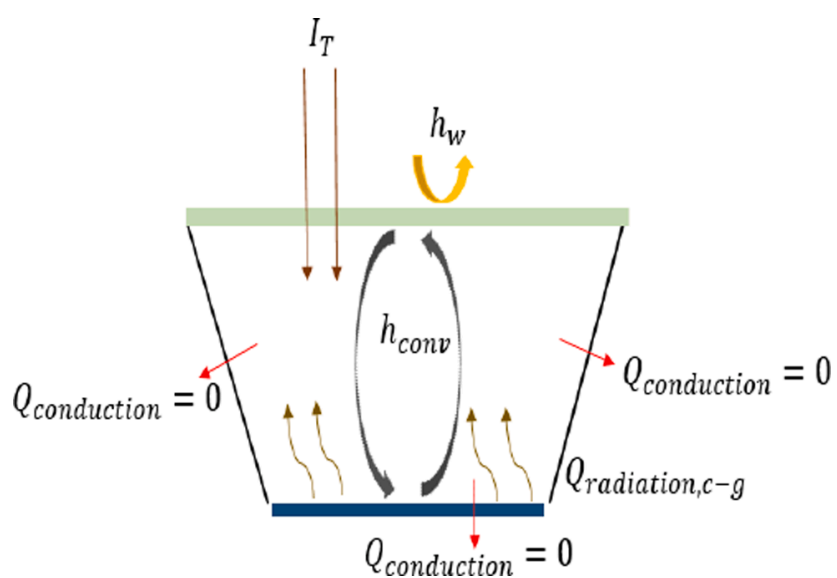

Fig. 10. Summary of boundary conditions employed in the thermal model.

$I_{\mathrm{T}}=I_{\mathrm{b}} R_{\mathrm{b}} \tau_{b}+I_{\mathrm{d}}\left(\frac{1+\cos \beta}{2}\right) \tau_{\mathrm{d}}+I \rho_{g}\left(\frac{1-\cos \beta}{2}\right) \tau_{\mathrm{d}}$

where $R_{b}$ is the ratio of beam irradiation on tilted surface to the horizontal surface and is calculated by using Eq. (7).

$R_{b}=\frac{\cos \left(\theta_{\mathrm{i}}\right)}{\cos \left(\theta_{\mathrm{z}}\right)}$

The angle of incidence $\left(\theta_{\mathrm{i}}\right)$ and the zenith angle $\left(\theta_{\mathrm{z}}\right)$ are calculated using Eqs. (8) and (9)

$\theta_{\mathrm{i}}=\cos ^{\overline{1}}(\sin \delta \sin \phi \cos \beta-\sin \delta \cos \phi \sin \beta \cos \gamma+\cos \delta \cos \phi \cos \beta \cos \omega$

$+\cos \delta \sin \phi \sin \beta \cos \gamma \cos \omega+\cos \delta \sin \beta \sin \gamma \sin \omega)$

$\theta_{\mathrm{z}}=\cos ^{\overline{1}}(\cos \phi \cos \delta \cos \omega+\sin \phi \sin \delta)$

where $\omega$,the hour angle and $\delta$, the declination angle, were calculated using Eqs. (10) and (11).

$\omega=\left(t_{\text {true }}-12.00\right) \times 15$

$\delta=23.45 \sin \left[\frac{360}{365}(284+n)\right]$

where $t_{\text {true }}$ is the solar time, determined from the movement of the sun, calculated using Eq. (12) and Eq. (13) [32].

$t_{\text {true }}=t_{\text {localmean }}+t_{\text {offset }}$

$t_{\text {offest }}=\mathrm{EOT}-4 L+60 t_{\text {zone }}$

where $t_{\text {localmean }}(\mathrm{min})$ indicates the local time, $L$ is the longitude of the location (East $>0$, West $<0$ ), $t_{\text {zone }}$ is the number of hours of the local time zone from the UT (East $>0$, West $<0$ ). EOT is the equation of time expressed in minutes and is calculated using Eqs. (14) and (15).

$$
\begin{aligned}
\mathrm{EOT} & =229.2(0.000075+0.001868 \cos B-0.032077 \sin B-0.014615 \cos 2 B \\
& -0.04089 \sin 2 B)
\end{aligned}
$$

$B=(n-1) \frac{360}{365}$

where $\mathrm{n}$ is the day number. (16).

Lastly, the power generated by the solar cells is calculated using Eq.

$P_{\text {out }}=I_{\mathrm{T}} A_{\text {aperture }} C_{\text {opt }} \eta_{\text {ele }}$

$C_{\mathrm{opt}}$ is the optical concentration and $\eta_{\mathrm{ele}}$ is the electrical conversion 
Table 3

Variables used in the thermal model.

\begin{tabular}{llll}
\hline Variables & Units & Value & Source \\
\hline Density of the cell (silicon), $\rho_{\text {cell }}$ & $\mathrm{kg} / \mathrm{m}^{3}$ & 2300 & {$[34]$} \\
Specific heat of the cell (silicon), $C_{p, \text { cell }}$ & $\mathrm{J} / \mathrm{kg}$. & 677 & {$[35]$} \\
& $\mathrm{K}$ & & \\
Absorptivity of cell (silicon), $\alpha_{\mathrm{ab}}$ & - & 0.9 & {$[36]$} \\
Temperature coefficient of the m-Si and p-Si & $\% /{ }^{\circ} \mathrm{C}$ & -0.36, & {$[37,38]$} \\
$\quad$ solar cells employed, $\beta_{\text {ref }}$ & & -0.41 & \\
Emissivity of the cell material, $\varepsilon_{\text {cell }}$ & - & 0.1 & {$[36]$} \\
Emissivity of the glass cover, $\varepsilon_{\text {glass }}$ & - & 0.9 & {$[36]$} \\
Thickness of the glass, $L_{\mathrm{T}}$ & $\mathrm{mm}$ & 3 & {$[36]$} \\
Thermal conductivity of air, $k_{\text {air }}$ & $\mathrm{W} / \mathrm{m}$. & 0.025 & {$[36]$} \\
& $\mathrm{K}$ & &
\end{tabular}

efficiency corresponding to the operating temperature.

\subsection{Model for predicting the thermal performance of the solar panels}

A thermal model for predicting the temperature of the solar PV cells has been developed. While predicting the conversion efficiency corresponding to the operating cell temperature, it has been assumed the boundaries of the concentrator are adiabatic excepting the glass aperture and the concentrator is tilted at an angle of $51.51^{\circ}$ facing south. Modes of energy exchange considered at various surfaces on the solar panels are shown in Fig. 10. The input parameters used in the thermal model are presented in Table 3.

As the heat transfer between the cell and the glass is due to natural convection, so the natural heat transfer coefficient $\left(h_{\text {conv }}\right)$ is calculated by using Eq. (17).

$h_{\text {conv }}=\frac{N u k_{\text {air }}}{L_{\mathrm{G}}}$

where $\mathrm{Nu}$ is the Nusslet number, $k_{\text {air }}(\mathrm{W} / \mathrm{m} . \mathrm{K})$ is the thermal conductivity at $25^{\circ} \mathrm{C}$ and $L_{\mathrm{G}}(40 \mathrm{~mm})$ is the vertical distance between the cell and the glass.

The collector is tilted at an angle so the Nusselt number can be calculated by using Eq. (18).

$N u=1+1.44\left[1-\frac{1708(\sin 1.8 \beta)^{1.6}}{R a \cos \beta}\right]\left[1-\frac{1708}{R a \cos \beta}\right]+\left[\left(\frac{R a \cos \beta}{5830}\right)^{0.3}-1\right]$

where $R a$ is the Rayleigh number and $\beta$ the tilt angle $\left(51.51^{\circ}\right)$.

The Rayleigh number has been calculated by using Eq. (19).

$R a=\frac{g \beta \Delta T L^{3}}{v \alpha}$

where $g\left(\mathrm{~m} / \mathrm{s}^{2}\right)$ is the gravitational constant, $\beta$ ' is the volumetric coefficient of expansion, $\Delta T(\mathrm{~K})$ is the temperature difference between cell and the glass cover, $v\left(\mathrm{~m}^{2} / \mathrm{s}\right)$ is the kinematic viscosity and $\alpha\left(\mathrm{m}^{2} / \mathrm{s}\right)$ is the thermal diffusivity.

Furthermore, beside natural convection, the radiative heat exchange between the cells and the glass cover was accounted in the model, for which the radiative heat transfer coefficient $\left(h_{r}\right)$, is calculated using the Eq. (20) [33].

$h_{r}=\frac{\sigma\left(T_{\text {cell }}^{2}+T_{\text {glass }}^{2}\right)\left(T_{\text {cell }}+\mathrm{T}_{\text {glass }}\right)}{\frac{1-\varepsilon_{\text {cell }}}{\varepsilon_{\text {cell }}}+\frac{1}{F}+\frac{\left(1-\varepsilon_{\text {glass }}\right) A_{\text {cell }}}{\varepsilon_{\text {glass }}}}$

where $\sigma$ is Stefan Boltzmann constant $\left(5.67 \times 10^{-8} \mathrm{~W} / \mathrm{m}^{2} \cdot \mathrm{K}^{4}\right), T_{\text {glass }}(\mathrm{K})$ is the glass cover temperature, $\varepsilon_{\text {cell }}, \varepsilon_{\text {glass }}$ are the emissivities of the cells and the glass respectively, $F$ is the view factor between cell and glass, $A_{\text {cell }}, A_{\text {glass }}$ is the cell and glass cover areas respectively.
Table 4

Variables used in the payback period calculations.

\begin{tabular}{lll}
\hline Investment & Cost $(£)$ & Source \\
\hline m-Si panel & 225 & {$[37]$} \\
p-Si panel & 185 & {$[38]$} \\
LCPV panel with m-Si solar cells & 250 & - \\
LCPV panel with p-Si solar cells & 204 & - \\
Supporting structure & 2000 & {$[38]$} \\
Installation costs & 1000 & - \\
Spare parts & 500 & {$[38,40]$} \\
\hline
\end{tabular}

The glass cover temperature is critical variable to be analyse because the heat gain is mainly due to convective and radiative heat transfer between the cell and the glass. The glass temperature $\left(T_{\mathrm{g}}\right)$ has been calculated by using the Eq. (21) [33].

$T_{\mathrm{g}}=\frac{\left(f T_{c}+T_{a}\right)}{(1+f)}$

where $T_{\mathrm{a}}$ is the ambient temperature, $T_{\mathrm{c}}$ is the cell temperature and $f$ is the ratio of inner (heat exchange between the cell and the inner glass cover) and outer (heat exchange between the outer glass cover and the ambient) heat transfer coefficient and is calculated by using Eq. (22).

$f=\frac{\left[\left(12 \times 10^{-8}\left(T_{\mathrm{a}}+0.2 T_{\mathrm{c}}\right)+h_{\mathrm{w}}\right]^{-1}+0.3 L_{G}\right.}{\left[6 \times 10^{-8}\left(\varepsilon_{\text {cell }}+0.0028\right)\left(T_{\mathrm{c}}+0.5 T_{\mathrm{a}}\right)^{3}+0.6 L_{T}^{-0.2}\left\{\left(T_{\mathrm{c}}-T_{\mathrm{a}}\right) \cos \beta\right\}^{0.25}\right]^{-1}}$

where $L_{T}$ is the thickness of the glass, $L_{G}$ is the vertical distance between cell and the glass, $h_{\mathrm{w}}$ is the wind heat transfer coefficient due forced convection on the top side of the glass cover and ambient and is calculated using Eq. (23) [28].

$h_{\mathrm{w}}=5.7+3.0 \mathrm{~V}$

where $V(\mathrm{~m} / \mathrm{s})$ is the wind speed.

The operating cell temperature $\left(T_{\mathrm{c} 2}\right)$ corresponding to the irradiation can be calculated by using Eq. (24). Overall, the energy balance of the solar collector, determines the operating cell temperature $\left(T_{\mathrm{c} 2}\right)$ calculated using the Eq. (24).

$T_{\mathrm{c} 2}=\frac{\alpha_{a b} I_{T}+\left(h_{\mathrm{conv}}+h_{r}\right) T_{g}+\rho_{\mathrm{cell}} \in_{\mathrm{cel} l} C_{p, \mathrm{cell}} T_{\mathrm{c} 1}}{h_{\mathrm{conv}}+h_{r} \rho_{\mathrm{cel} l} \in_{\mathrm{cell}} C_{p, \mathrm{cell}}}$

Finally, the cell conversion efficiency $\left(\eta_{\mathrm{ele}}\right)$ has been evaluated by using Eq. (25).

$\eta_{\text {ele }}=\eta_{\mathrm{T}, \text { ref }}\left[1-\beta_{\text {ref }}\left(T_{\mathrm{c} 2}-T_{\mathrm{PV}, \text { ref }}\right)\right]$

\subsection{Payback period calculations}

A spreadsheet-based model has been developed to predict the payback period, time required for a capital investment to generate a positive cash flow, of LCPV panels and flat PV panels in conjunction with $\mathrm{m}-\mathrm{Si}$ and $\mathrm{p}-\mathrm{Si}$ solar cells.

Payback period calculations have considered 12 panels of $340 \mathrm{Wp}$ (LCPV and flat PV panel configurations) summed up to a total $4 \mathrm{kWp}$ solar PV array installed in London (UK) at a tilt angle of $51.51^{\circ}$ facing south. It has been assumed that solar cell efficiency, measured under solar simulator is equal to the module efficiency. Unit price of electricity of $£ 0.1174 / \mathrm{kWh}$ has been adopted [39]. Table 4 shows the economic parameters considered by the model. For predicting the payback period calculations, LCPV panels have been assumed to cost $10 \%$ higher than conventional PV panels. 


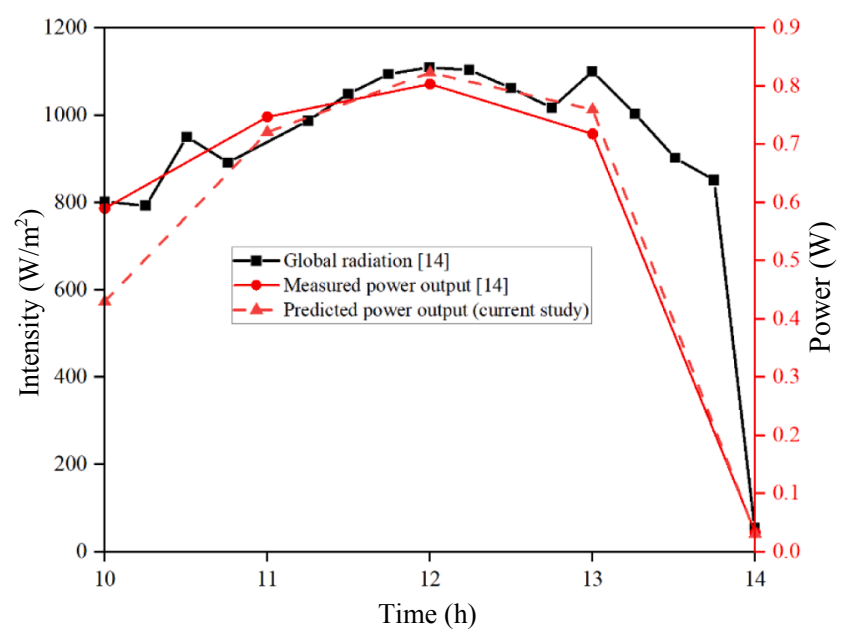

Fig. 11. Power generated by flat PV $\mathrm{m}-\mathrm{Si}$ solar cell during the testing hours from $10: 00$ to $14: 00$.

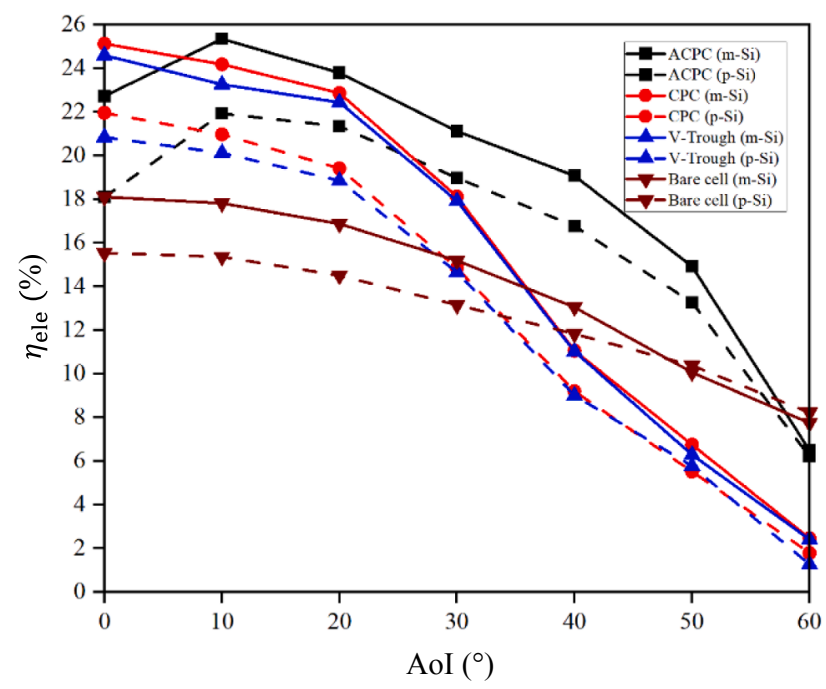

Fig. 12. The electrical conversion efficiencies of the developed LCPV systems in conjunction with c-Si solar cells at $1000 \pm 2 \% \mathrm{~W} / \mathrm{m}^{2}$.

\subsection{Validation of the energy output model}

The analytical model developed in the current study has been validated through an experimental investigation reported by Hadavinia and Singh [14]. The model was inputted with the cell area of $25 \mathrm{~mm} \times 125$ $\mathrm{mm}$, solar radiation (direct and diffuse) measured on $20^{\text {th }}$ September and the electrical conversion efficiency 19.4\%. From Fig. 11, the power output predicted by the energy output model showed a deviation of $11.3 \%$ (highest) from the experimental data. The deviation between analytical (current study) and experimentally measured power output [14] may have occurred due to the different values of input parameters, such as ambient temperature, wind speed and cell temperature, employed by the model. Weather data used by the model was sourced from the reference year data for London as available in the Energy Plus library [27].

\section{Results and discussion}

\subsection{Electrical conversion efficiency measurements}

The measured electrical conversion efficiencies $\left(\eta_{\text {ele }}\right)$ of the $\mathrm{m}$-Si and p-Si solar cells in conjunction with the CPV prototypes are shown in

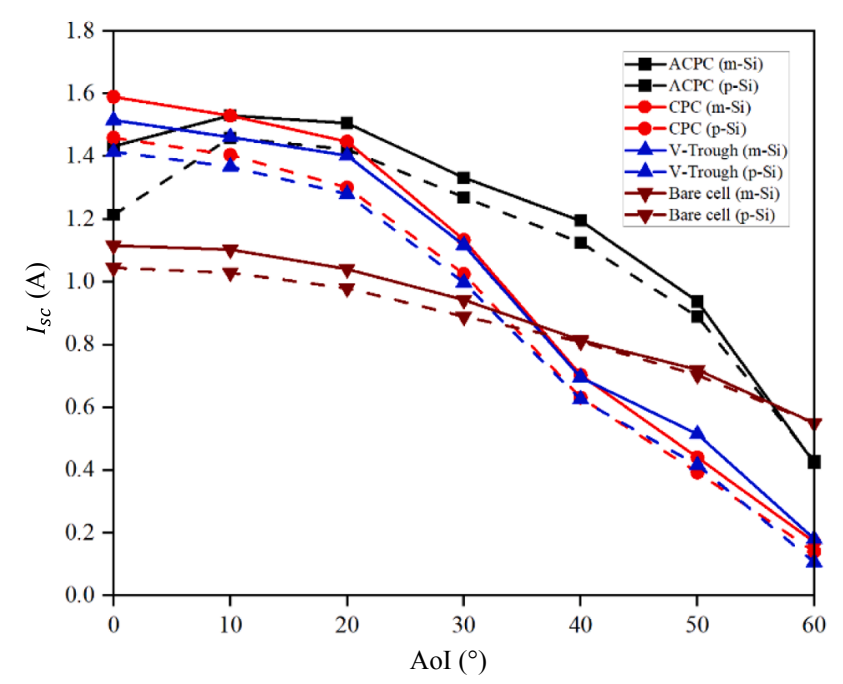

Fig. 13. The short circuit current generated by the developed LCPV systems in conjunction with c-Si solar cells.

Fig. 12. Performances of solar cells under one-sun condition are also shown. Solar radiation intensity of $1000 \pm 2 \mathrm{~W} / \mathrm{m}^{2}$ supplied by the solar simulator were employed for the tests. Cells were tested first under onesun and then in conjunction with the developed optical concentrators. Measurements have shown that $\mathrm{m}$-Si cell in conjunction with the CPC panel achieved an efficiency of $25.12 \%$ with a maximum power $\left(P_{\max }\right)$ of $0.74 \mathrm{~W}$ at $0^{\circ}$ angle of incidence followed by V-trough, ACPC and nonconcentrated cell with conversion efficiencies $24.59 \%, 22.72 \%$, $18.11 \%$ respectively. At $0^{\circ}$ angle of incidence, p-Si cell recorded an electrical conversion efficiency of $21.95 \%$ with CPC followed by VTrough, ACPC and non-concentrated configuration at 20.83\%, $18.09 \%$ and $15.54 \%$, respectively. Further, for angles of incidence $>0^{\circ}$ (from $10^{\circ}$ to $60^{\circ}$ studied), ACPC panels achieved higher electrical conversion efficiencies than other concentrator panels for both cells $\mathrm{m}$ and $\mathrm{p}-\mathrm{Si}$ cells. For example, ACPC achieved $42.2 \%$ higher electrical efficiency for $\mathrm{m}-\mathrm{Si}$ cell than a non-concentrated $\mathrm{m}-\mathrm{Si}$ cell at AoI $10^{\circ}$.

\subsection{Effect of short circuit current on electrical conversion efficiency of solar cells}

The effect of concentration on the current generated by the solar cells is presented in Fig. 13. The short circuit current $\left(I_{s c}\right)$ increased with the concentration, thus increasing the electrical conversion efficiency of the solar cell. As expected, m-Si cells performed better than $\mathrm{p}$-Si cells. The measurements have been performed with flash simulator, therefore is no rise in cell temperature detailed. In addition, the short circuit current generated by the LCPV panels showed a decreasing trend as the AoI increased, which is attributed to the cosine effect, see Fig. 14. Cosine effect is the reduction in illuminated area on the receiver due the cosine angle formed between the direction of sun rays and normal to the receiver plane [41]. The reduction of the illuminated area is not equivalent in all the concentrators due to the acceptance angle of the LCPV geometric configuration. As the AoI increases the shaded area increases (see Fig. 14), thereby reducing the power output of the LCPV panels. In addition, as AoI increases, the shaded area increases with increasing non-uniformity reducing the power produced by the cell and causing non-homogenous temperature gradient across the LCPV panel. Number of hours for which cell will be shaded (partially or fully) for ACPC, CPC and V-Trough geometries have been predicted to be $2555 \mathrm{~h}$, 2856 h, 3534 h respectively for London. 


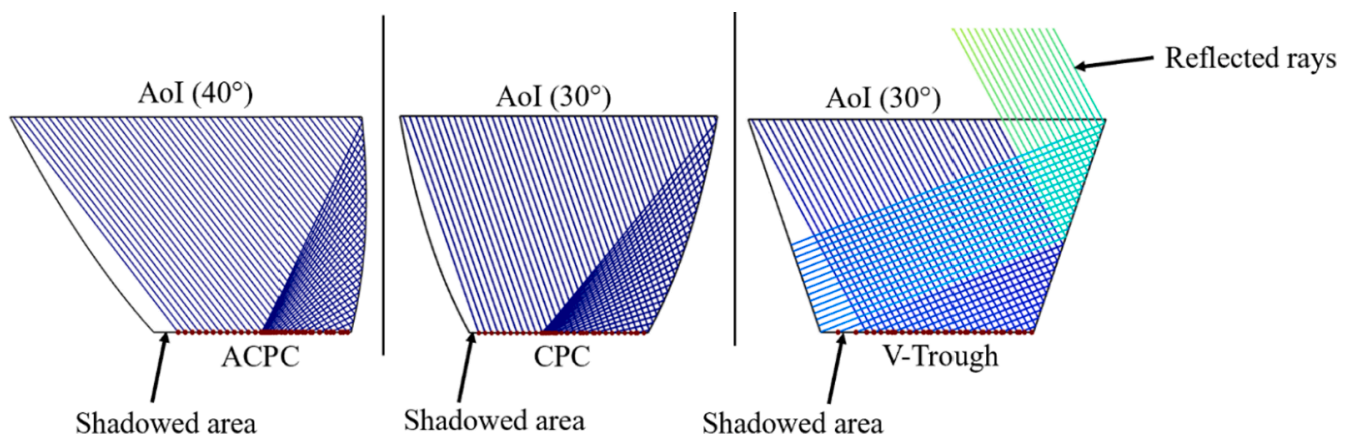

Fig. 14. Representation of reduction of illuminated area on the receiver due to cosine effect.

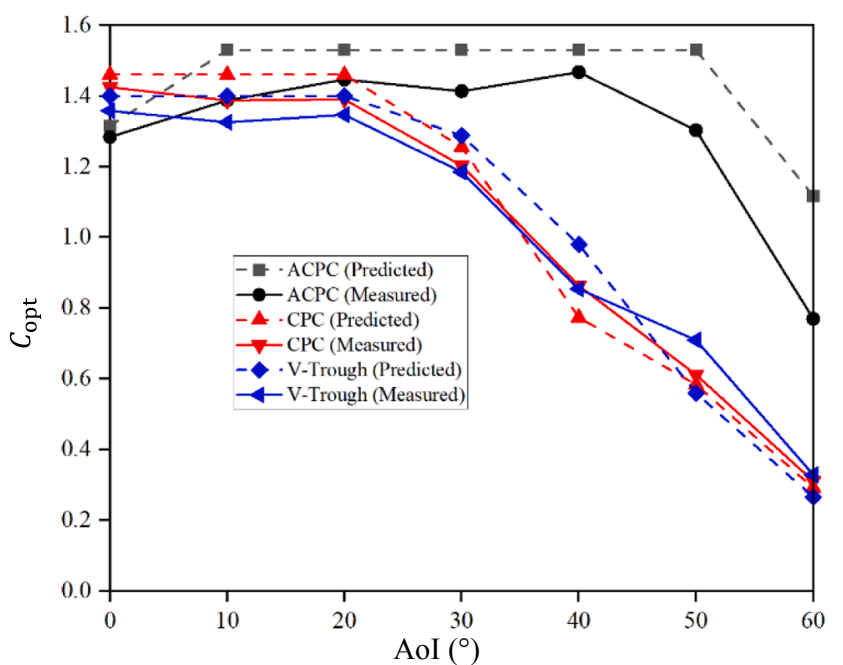

Fig. 15. The variation of the simulated and measured optical concentration against AoI of the LCPV systems developed.

\subsection{The effect of angle of incidence on the optical concentration of LCPV systems}

The developed LCPV panels showed an excellent agreement between the experimental and simulated optical concentration, see Fig. 15. The experimental characterisation of the optical efficiency of CPC, V-Trough and ACPC showed the deviation (highest) of 4.36\%, 7.8\% and $16.03 \%$ from the 2-D ray tracing simulation respectively. The optical concentration ratio depends on the shape and the reflectivity of the reflector. The deviation between the experimental and simulation results can be explained by manufacturing defects in the concentrator substrate, reflector misalignment, and misaligning the optical sensors at the receiver.

\subsection{Global and diffuse irradiation}

In London, in a typical year, out of a total $4399 \mathrm{~h}$ of sunlight, magnitude of hourly diffuse radiation on a horizontal surface is greater than direct radiation for $2963 \mathrm{~h}$ [27]. London receives approximately $996 \mathrm{kWh} / \mathrm{m}^{2}$ of global horizontal irradiation and $556 \mathrm{kWh} / \mathrm{m}^{2}$ of diffuse horizontal irradiation, making the latter a critical factor to be accounted for when designing CPVs for London. To maximise the use of diffuse light, optical designs of three LCPV systems with $C_{\mathrm{g}}<3$ have been optimised in this study.

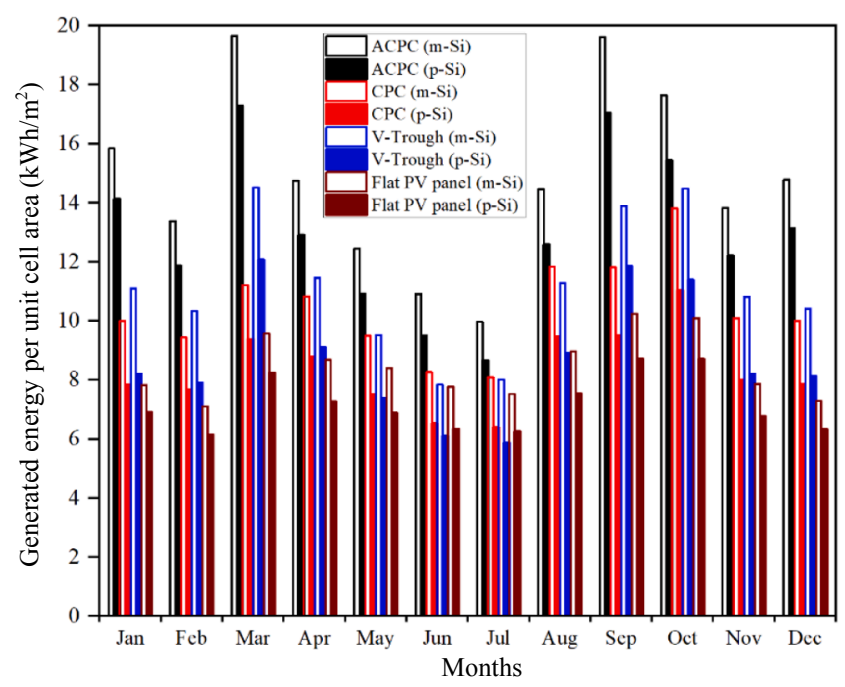

Fig. 16. Comparison of predicted monthly cumulative power generation of LCPV concentrators with that of the flat PV panels.

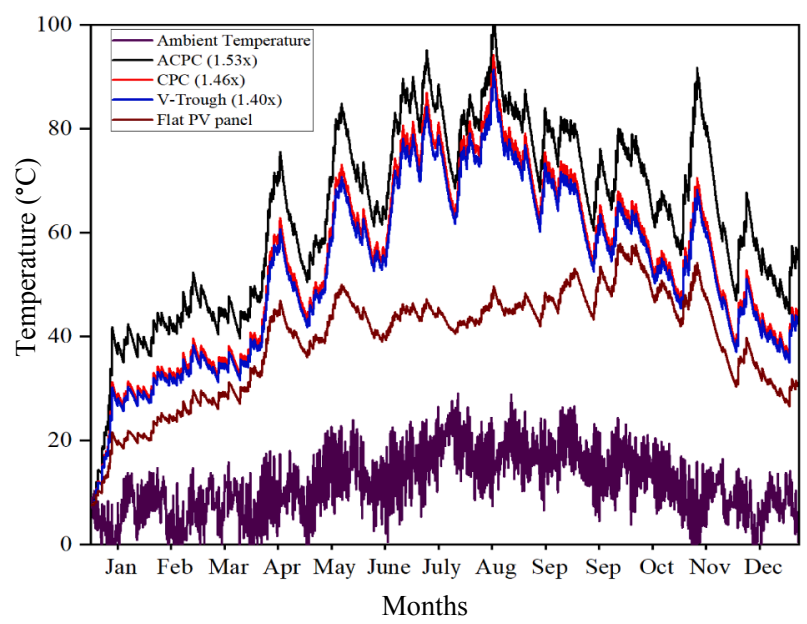

Fig. 17. Operating cell temperatures of LCPV panels and flat PV module and the ambient temperature of London.

\subsection{Comparison of the predicted energy output per unit cell area and the operating cell temperatures}

The predicted energy output per unit cell area of the developed LCPV configurations and the flat PV modules in conjunction with $\mathrm{m}-\mathrm{Si}$ and $\mathrm{p}-\mathrm{Si}$ solar cells are illustrated in Fig. 16. An equivalent cell area of $13.32 \mathrm{~m}^{2}$ 

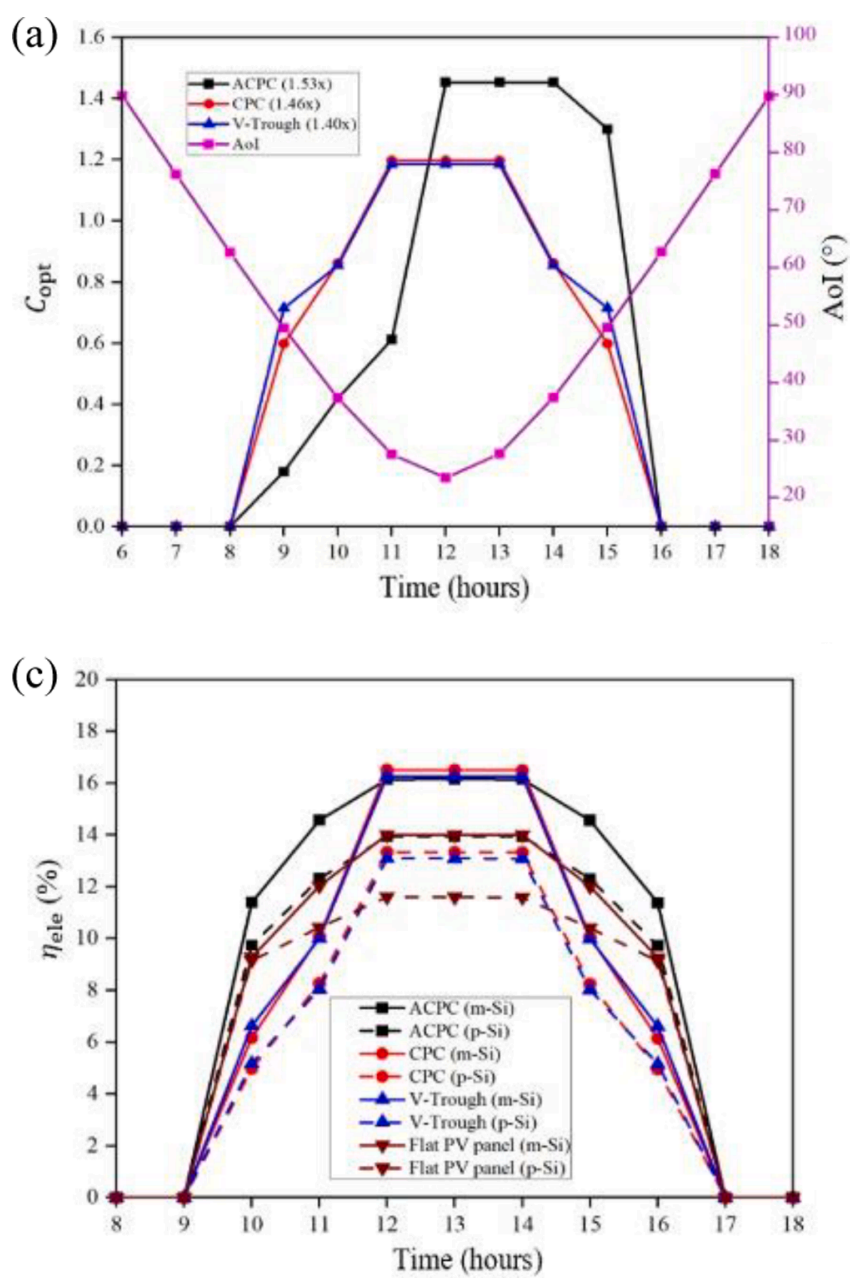

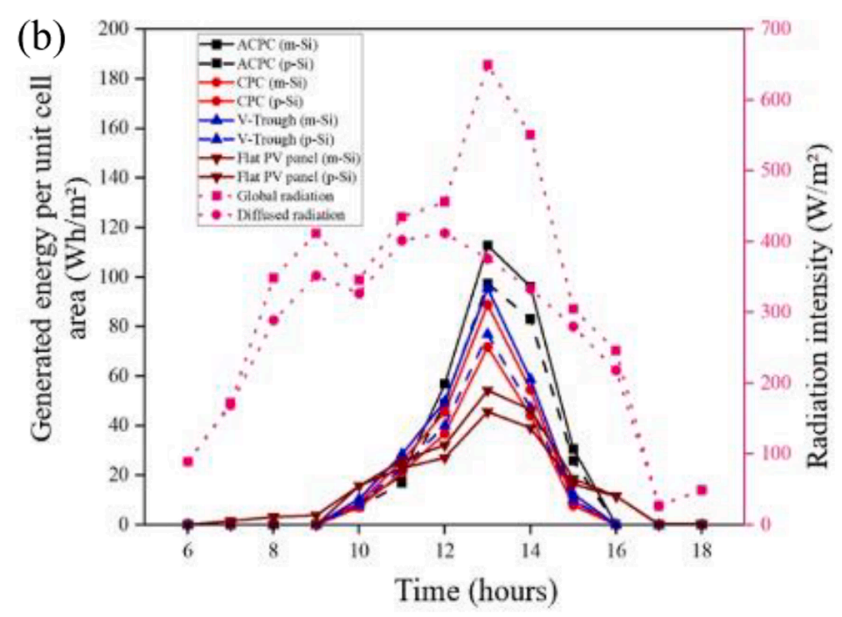

(d)

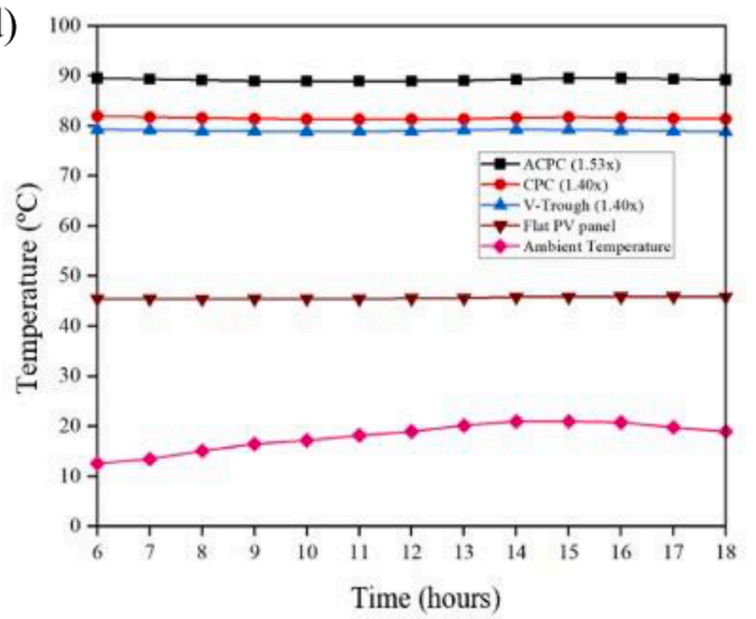

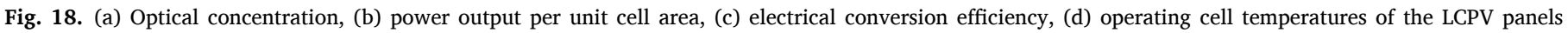
predicted for $21^{\text {st }}$ June.

was considered for all cases investigated. The cumulative energy output of ACPC, per unit cell area, with m-Si cell was $177 \mathrm{kWh} / \mathrm{m}^{2}$ followed by V-Trough, CPC and flat PV module at $134 \mathrm{kWh} / \mathrm{m}^{2}, 125 \mathrm{kWh} / \mathrm{m}^{2}$ and $101 \mathrm{kWh} / \mathrm{m}^{2}$ respectively. On the other hand, ACPC, per unit cell area, with p-Si generated $156 \mathrm{kWh} / \mathrm{m}^{2}$ followed by V-Trough, CPC and flat pSi PV panel with $105 \mathrm{kWh} / \mathrm{m}^{2}, 99 \mathrm{kWh} / \mathrm{m}^{2}$ and $86 \mathrm{kWh} / \mathrm{m}^{2}$ respectively. Results showed that the ACPC with $\mathrm{m}$-Si generated higher energy output annually as compared to the other configurations. It can be seen from Fig. 16, during the months of May to August, the LCPVs' performance decreases due to elevated operating cell temperatures (see Fig. 17). When no active cooling was considered, solar cell temperatures with ACPC panels were predicted to be consistently the highest among all modules considered.

The operating cell temperature, energy output, AoI and electrical conversion efficiency for $21^{\text {st }}$ June (summer solstice) are presented in Fig. 18. ACPC achieved the highest optical concentration during 12:00 to 16:00 among all configurations studied, see Fig. 18(a). The higher optical concentration of ACPC resulted into the highest energy output and electrical conversion efficiency as compared to the other concentrators and the flat PV modules, see Fig. 18(b) and Fig. 18(c).

Furthermore, ambient temperature and the operating cell temperatures of LCPV panels are shown in Fig. 18(d). However, the trend of cell temperature and solar irradiation is not same, see Fig. 18 (b), as the heat loss from the concentrator exists only through the glass cover (as concentrator walls and the cells are adiabatic, see Fig. 10). Moreover, the effect of cell temperature on the electrical conversion efficiency can be understood when the cell temperature is equal to the ambient

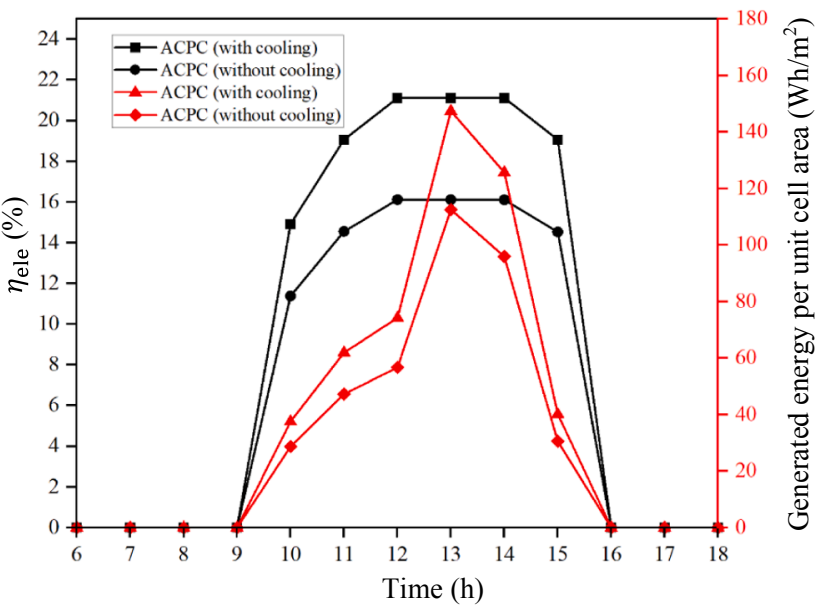

Fig. 19. Electrical conversion efficiency and the energy output of ACPC module with active cooling (operating cell temperatures maintained at $25{ }^{\circ} \mathrm{C}$ ) and without cooling.

temperature $\left(25^{\circ} \mathrm{C}\right)$, the electrical conversion efficiency of the ACPC is $25.12 \%$ at AoI $10^{\circ}$ (see Fig. 12). However, at same AoI, the predicted operating cell temperature is $90{ }^{\circ} \mathrm{C}$ (ACPC), the electrical conversion efficiency reduces to $15.8 \%$, see Fig. 18 (c), that indicates the significance of cooling the solar PV cells. 


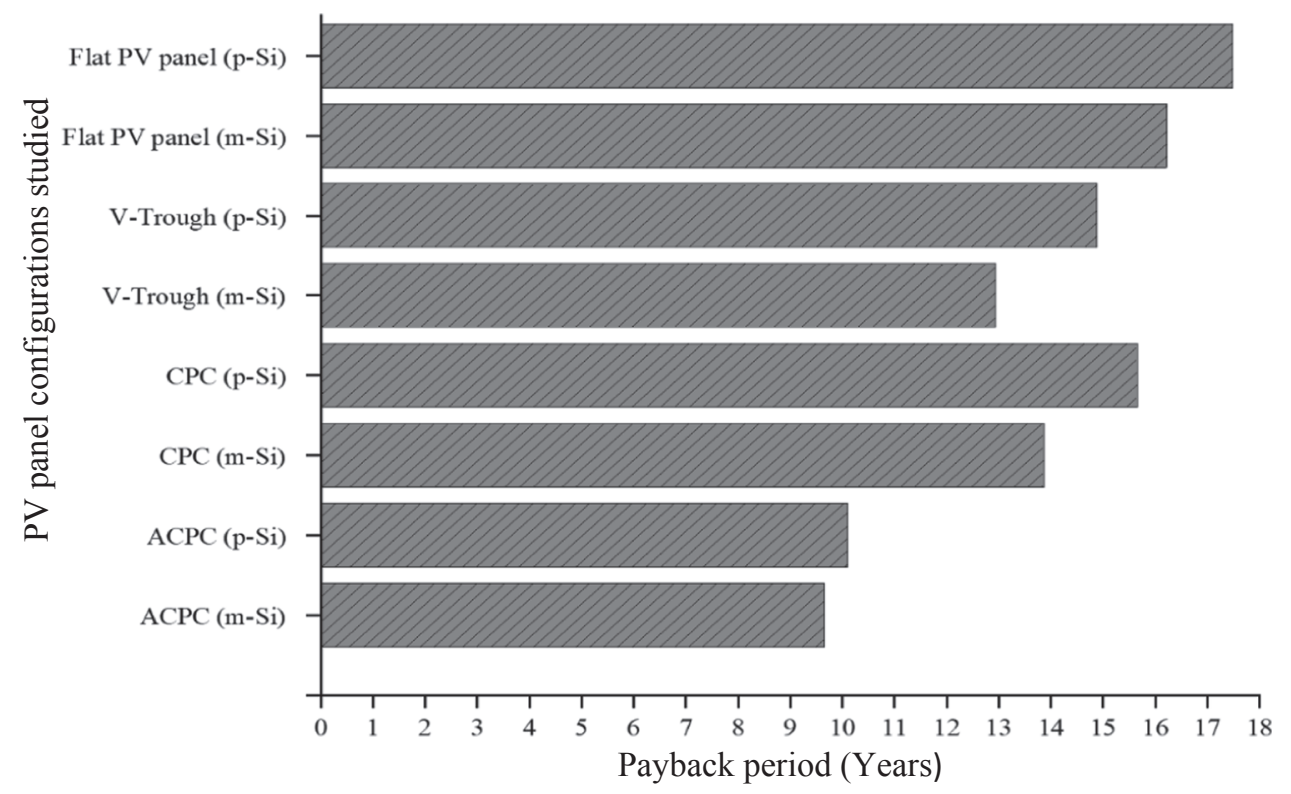

Fig. 20. Payback period predicted for the LCPV and flat PV panel.

The comparison of the generated energy output per unit cell area and the electrical conversion efficiency of the ACPC with and without active cooling, see Fig. 19. Results showed that generated energy output and the conversion efficiency of ACPC with active cooling increased by $31 \%$ when compared ACPC with no cooling effect. Also, it should be noted that the temperature difference $\left(60^{\circ} \mathrm{C}\right)$ can be used for the domestic heating applications. The main benefit of deploying LCPV panels for buildings account higher power generation and the possibility of generating heat for domestic applications will reduce building's energy requirements.

6.6. Payback period prediction of LCPV panels in conjunction with $\mathrm{m}$-Si and p-Si solar PV cells

The payback periods estimated for the LCPVs developed without considering any feed-in-tariffs are shown in Fig. 20. Simulations have showed that ACPC panel with $\mathrm{m}$-Si solar cells achieved the lowest payback period of 9.7 years when compared to CPC, V-Trough and flat $\mathrm{m}$-Si PV modules with 13.8 years, 12.94 years and 16 years respectively. For p-Si cells, ACPC still showed the shortest payback period of 10.05 years, see Fig. 20. In addition, results in the previous sections showed that truncated LCPV systems could perform higher when hybridised as photovoltaic-thermal system (PVT) by generating more power whilst simultaneously supplying hot water. This will help them achieving a lower payback period benefitting the plant owners and higher profits for $\mathrm{PV}$ industry.

\section{Conclusions}

In this study, the potential of LCPV panels using low cost c-Si solar cells has been analysed by investigating the technical and economic performances.

LCPV concentrator geometries were designed and simulated to predict ray acceptance at range of angles of incidence using ray trace module in COMSOL Multiphysics.

The manufactured prototypes were tested under OAI simulator and measurements have shown that ACPC achieved 42.2\% higher electrical efficiency for $\mathrm{m}$-Si cell than a non-concentrated $\mathrm{m}$-Si cell at $10^{\circ}$ AoI.

An analytical model was developed to predict the energy generation capacity and the payback period of the LCPVs configurations when compared to flat PV modules installed in London. ACPC panel with $\mathrm{m}-\mathrm{Si}$ solar cells generated $177 \mathrm{kWh} / \mathrm{m}^{2}$ with a payback period of 9.7 years as compared to flat m-Si PV panels with $101 \mathrm{kWh} / \mathrm{m}^{2}$ with a payback period of 16 years respectively.

Due to the elevated operating cell temperatures during summer the overall performance of LCPVs decreases when no active cooling was considered. Maintaining cell temperatures at $25^{\circ} \mathrm{C}$ on June $21^{\text {st }}$ through active cooling increased the power produced by $31 \%$ by ACPC.

It can be determined that LCPVs systems can improve the energy output and contribute to part of the heating load as compared to a nonconcentrating PV panel with the same amount of semi conducting material. Generating higher energy output make the LCPVs for the building retrofit more attractive and therefore contribute to nearly zero-energy buildings.

\section{CRediT authorship contribution statement}

Ranga Vihari: Conceptualization, Methodology, Writing- Original draft preparation, Visualization, Investigation, Software and experimental validation. Harjit Singh: Conceptualization, Supervision, Project administration. Maria Kolokotroni: Supervision, Project administration.

\section{Declaration of Competing Interest}

The authors declare that they have no known competing financial interests or personal relationships that could have appeared to influence the work reported in this paper.

\section{Acknowledgement}

This project has received funding from the European Union's H2020 research and innovation programme under grant agreement no 768576.

\section{References}

[1] Li Y, Kubicki S, Guerriero A, Rezgui Y. Review of building energy performance certification schemes towards future improvement. Renew Sustain Energy Rev 2019;113:109244. https://doi.org/10.1016/j.solener.2014.03.002 16/j. rser.2019.109244.

[2] BPIE. Building Renovation Passports - Customised roadmaps towards deep renovation and better homes. http://bpie.eu/publication/renovation-passports/ ;2019 [accessed:28 December 2019]. 
[3] Renewables 2019. Market and forecast from 2019 to 2024, https://www.iea.org/ reports/renewables-2019; 2019 [Cited: 18 April 2019].

[4] NREL. Current Status of Concentrator Photovoltaic (CPV) Technology, https:// www.nrel.gov/docs/fy16osti/65130.pdf ; 2015 [accessed: 24 December 2019].

[5] Madala S, Boehm RF. A review of nonimaging solar concentrators for stationary and passive tracking applications. Renew. Sustain. Energy Rev. 2017;71:309-22. https://doi.org/10.1016/j.rser.2016.12.058.

[6] Winston R. Principles of solar concentrators of a novel design. Sol. Energy 1974;16: 89-95. https://doi.org/10.1016/0038-092X(74)90004-8.

[7] Hasan HA, Sopian K, Jaaz AH, Al-Shamani AN. Experimental investigation of jet array nanofluids impingement in photovoltaic/thermal collector. Sol Energy 2017; 144:321-34. https://doi.org/10.1016/j.solener.2017.01.036.

[8] Baig H, Sellami N, Chemisana D, Rosell J, Mallick TK. Performance analysis of a dielectric based 3D building integrated concentrating photovoltaic system. Sol Energy 2014;103:525-40. https://doi.org/10.1016/j.solener.2014.03.002.

[9] Sukki FM, Siti Hawa Abu-Bakar SH, Iniguez RR, McMeekin SG, Stewart BG, et al. Mirror symmetrical dielectric totally internally reflecting concentrator for building integrated photovoltaic systems. Appl Energy 2014;113:32-40. https://doi.org/ 10.1016/j.apenergy.2013.07.010.

[10] Shaltout MAM, Ghettas A, Sabry M. V-trough concentrator on full tracking system in a hot desert climate. Renew Energy 1995;6:527-32. https://doi.org/10.1016/ 0960-1481(95)00055-O.

[11] Sangani CS, Solanki CS. Experimental evaluation of V-trough (2 suns) PV concentrator system using commercial PV modules. Sol Energy Mater Sol Cells 2007;91:453-9. https://doi.org/10.1016/j.solmat.2006.10.012.

[12] Baig H, Jani R, Markam BK, maiti S, Mallick TK. Modelling and experimental analysis of a seasonally tracked V-Trough PV/T system in India. Sol Energy 2018; 170(618-632). https://doi.org/10.1016/j.solener.2018.06.018.

[13] Elminshawy NAS, El-Ghandour M, Elhenawy Y, Bassyouni M, El-Damhogi DG, Addas MF. Experimental investigation of a V-trough PV concentrator integrated with a buried water heat exchanger cooling system. Sol Energy 2019;193:706-14. https://doi.org/10.1016/j.solener.2019.10.013.

[14] Hadavinia H, Singh H. Modelling and experimental analysis of low concentrating solar panels for use in building integrated and applied photovoltaic (BIPV/BAPV) systems. Renew Energy 2019;139:815-29. https://doi.org/10.1016/j. renene.2019.02.121.

[15] Zacharopoulos A, Eames PC, McLarnon D, Norton B. Linear dielectric non-imaging concentrating covers for PV integrated building facades. Sol Energy 2000;68: 439-52. https://doi.org/10.1016/S0038-092X(00)00013-X.

[16] Mallick TK, Eames PC, Hyde TJ, Norton B. The design and experimental characterisation of an asymmetric compound parabolic photovoltaic concentrator for building façade integration in the UK. Sol Energy 2004;77:319-27. https://doi. org/10.1016/j.solener.2004.05.015.

[17] Mallick TK, Eames PC, Norton B. Power losses in an asymmetric compound parabolic photovoltaic concentrator. Sol Energy Mater Sol Cells 2007;91:1137-46. https://doi.org/10.1016/j.solmat.2007.03.020.

[18] Mallick TK, Eames PC. Design and fabrication of low concentrating second generation PRIDE concentrator. Sol Energy Mater Sol Cells 2007;91:597-608. https://doi.org/10.1016/j.solmat.2006.11.016.

[19] Lu W, Wu Y, Eames PC. Design and development of a building façade integrated asymmetric compound parabolic photovoltaic concentrator (BFI-ACP-PV). Appl Energy 2018;220:325-36. https://doi.org/10.1016/j.apenergy.2018.03.071.

[20] Fraidenraich N, Almeida GJ. Optical properties of V-trough concentrators. Sol Energy 1991;47:147-55. https://doi.org/10.1016/0038-092X(91)90073-6.

[21] Winston R, Minano JC, Benitez P. Nonimaging optics. third ed. Massachusetts: Academic press; 2005.
[22] Carvalho MJ, Collares-Pereira M, Gordon JM, Rabl A. Truncation of CPC solar collectors and its effect on energy collection. Sol Energy 1985;35:393-9. https:// doi.org/10.1016/0038-092X(85)90127-6.

[23] Rabl A. Comparison of solar concentrators. Sol Energy 1976;18:93-111. https:// doi.org/10.1016/0038-092X(76)90043-8.

[24] Li L, Wang B, Pottas J, Lipiński W. Design of a compound parabolic concentrator for a multi-source high-flux solar simulator. Sol Energy 2019;183:805-11. https:// doi.org/10.1016/j.solener.2019.03.017.

[25] Alanod. Alanod MIRO-SILVER $R$, ; z2019 [accessed: 26 December 2019].

[26] OSRAM. OSRAM Optosemiconductors GmbH, https://www.osram.com/ecat/ Radial\%20T1\%203-4\%20SFH\%20203\%20P/com/en/class_pim_web_catalog_ 103489/global/prd_pim_device_2219552/; 2019[accessed: 24 December 2019].

[27] Energy Plus. Energy Plus Weather Data, https://energyplus.net/weather 2019 [accessed: 08 January 2020].

[28] Duffie JA, Beckman WA. Solar Engineering of Thermal Processes. Third Edition. New York: John Wiley and Sons; 1991.

[29] Sanchez-Palencia P, Martin-Chivelet N, Chenlo F. Modelling temperature and thermal transmittance of building integrated photovoltaic modules Sol. Energy 2019;184:153-61. https://doi.org/10.1016/j.solener.2019.03.096.

[30] Orioli A. An accurate one-diode model suited to represent the current-voltage characteristics of crystalline and thin-film photovoltaic modules. Renew Energy 2020;145:725-43. https://doi.org/10.1016/j.renene.2019.06.074.

[31] Lurwan SM, Mariun N, Hizam H, Radzi MAM, Zakaria A. Predicting power output of photovoltaic systems with solar radiation model. IEEE International Conference on Power and Energy (PECon) 2014:304-8.

[32] Da Rosa AV. Fundamentals of renewable energy processes. 3rd ed. California: Elsevier; 2013.

[33] Akhtar N, Mullick SC. Computation of glass-cover temperatures and top heat loss coefficient of flat-plate solar collectors with double-glazing. Energy 2007;32: 1067-74. https://doi.org/10.1016/j.energy.2006.07.007.

[34] Hoang P, Bourdin V, Liu Q, Caruso G, Archambault V. Coupling optical and thermal models to accurately predict PV panel electricity production. Sol Energy Mater Sol Cells 2014;125:325-38. https://doi.org/10.1016/j.solmat.2013.11.032.

[35] Guarracino I, Mellor A, Ekins-Daukes NJ, Markides CN. Dynamic coupled thermaland-electrical modelling of sheet-and-tubehybrid photovoltaic/thermal (PVT) collectors. Appl Therm Eng 2016;101:778-95. https://doi.org/10.1016/j. applthermaleng.2016.02.056.

[36] Zondag HA, de Vries DW, van Helden WGJ, van Zolingen RJC, van Steenhoven AA. The yield of different combined PV-thermal collector designs. Sol Energy 2003;74: 253-69. https://doi.org/10.1016/S0038-092X(03)00121-X.

[37] LG Solar PV panels. Wind and Sun, http://www.windandsun.co.uk/products/ Solar-PV-Panels/LG-Solar-PV-Panels\#.XtuLjkVKg2w [accessed: 26 December 2019].

[38] Crystalline Solar panels, Sunshine solar, https://www.sunshinesolar.co.uk/ Category/CrystallinePanels [acessed:26 December 2019].

[39] British Gas. British Gas, https://www.britishgas.co.uk/GetAQuote/\#/new/quotedetails; 2019[accessed:28 December 2019].

[40] Solis 4kw grid tie Solar Inverter 4G Dual MPPT, ITS Technologies, https://www. itstechnologies.shop/products/solis-mcs-solar-inverter-4-0kw-4g-dual-mppt-fullrange-avaialble-trade-prices?variant $=29297423974452$ \& currency $=$ GBP\&utm source $=$ google\&utm_medium $=$ cpc\&utm_campaign $=$ google + shopping\&utm campaign $=$ gs-2020-02-25\&utm_source $=$ google\&utm_medium $=$ smart_ campaign\&gclid=Cj0KCQjw_ez2BRCyARIsAJfgks0y5kaODcIcFj4KF5o0qq4J14MdHwbA6XR2EIC0z6V69Zdi23ITo0aAuAZEALw_ wcB.

[41] Sarmah N, Richards BS, Mallick TK. Design, development and indoor performance analysis of a low concentrating dielectric photovoltaic module. Sol. Energy 2014; 103:390-401. https://doi.org/10.1016/j.solener.2014.02.029. 